\author{
Saška Štumberger \\ Filozofska fakulteta, Ljubljana \\ DOI: $10.4312 /$ SSJLK.57.21-28
}

\title{
Raba ženskih slovničnih oblik v slovenskem knjižnem jeziku
}

\begin{abstract}
Slovenščina spada med spolno občutljive jezike, kajti kategorijo spola izraža pri samostalniku, pridevniku, glagolu in zaimku. Veliko možnosti za izražanje kategorije spola v slovnici se kaže v slovenskem besedotvornem sistemu, ki - najpogosteje po postopku izpeljave - ponuja možnosti za tvorjenje poimenovanj za ženske osebe. V prispevku bo predstavljena raba ženskih oblik v besedilih, ki kaže na večjo prisotnost žensk v javnem življenju, kajti raba ženskih slovničnih oblik je povezana s poimenovanjem ženskih oseb, medtem ko se moške slovnične oblike rabijo v dveh pomenih: za poimenovanje moških oseb in spolno nezaznamovano.
\end{abstract}

slovnični spol, slovenščina, jezikovni sistem, jezikovna raba, ženske slovnične oblike

Slovene is a gender sensitive language, with the category of gender being expressed with nouns, adjectives, verbs and pronouns. The extensive possibilities for grammatical expression of gender can be seen in the word formation system, which offers, usually through the procedure of derivation, the chance of forming an expression for the female person. This paper presents the use of feminine forms in texts that point to the greater presence of women in public life, for the use of female grammatical forms is connected with expressions for female persons, whereas the use of male grammatical forms has two meanings: expressions for male persons and for gender unmarked.

grammatical gender, Slovene, language system, language use, female grammatical forms

\section{Slovenski jezikovni sistem}

Spol je kategorija za razvrščanje samostalnikov v tri sklanjatve - moško, žensko in srednjo, pri moški sklanjatvi ločimo še kategorijo živosti, ki se kaže $v$ ujemanju rodilnika in tožilnika pri samostalnikih moškega spola $v$ ednini. Pri samostalniku, pridevniku in zaimku ločimo šest sklonov: imenovalnik, rodilnik, dajalnik, tožilnik, mestnik in orodnik. Pregibne besedne vrste $v$ slovenščini ločijo tri števila: ednino, dvojino za označevanje dveh in množino za označevanje več kot dveh zunajjezikovnih danosti.

Vsi samostalniki v slovenščini imajo določen slovnični spol; to velja tudi za tiste, ki poimenujejo neživo, npr. miza (ženski spol), oblak (moški spol) ali sonce (srednji spol). Kadar pri poimenovanju oseb izhajamo iz njihove »biološke funkcije pa tudi rodovne oziroma družinske vezanosti« (Vidovič Muha 1997: 70), imamo za poimenovanja moških in ženskih oseb besedotvorno nepovezane lekseme, pri katerih ima "poimenovanje moškega [...] dopolnjevalni protipomenski par v poimenovanju ženske: ženska - moški, žena - mož, deklica - deček, mati - oče« (prav tam). Taka poimenovanja imajo tudi izrazno samostojne nadpomenke, npr. oseba je nadpomenka ženski in moškemu, zakonec ženi in možu, otrok deklici in dečku, starši materi in očetu.

Pri poimenovanjih oseb po družbenih funkcijah ali dejavnostih nimamo izrazno samostojnih nadpomenk. $V$ takih primerih je izraz za poimenovanje osebe večpomenski - rabimo ga kot spolno nezaznamovan izraz, z njim pa poimenujemo tudi moške osebe. Nezaznamovanost kategorije 
spola se v slovarskih razlagah kaže z rabo spolno nezaznamovanega zaimka kdor ali nadpomenk oseba in bitje. V razlagalnem Slovarju slovenskega knjižnega jezika 2 (SSKJ2) imamo za samostalnike moškega slovničnega spola naslednje razlage: učitelj »kdor (poklicno) uči, poučuje«, antijunak »1. negativna ali nedejavna glavna literarna oseba v nasprotju z aktivno delujočim junakom«, bog »1. ed., v enoboštvu nadnaravno bitje, ki je ustvarilo svet in ki posega v njegov razvoj«.

Zaimek kdor ter samostalnika oseba in bitje ne izražajo niti ženskega niti moškega biološkega spola in so v slovarskih razlagah rabljeni spolno nezaznamovano.

Razlage samostalnikov ženskega slovničnega spola so spolno zaznamovane z nadpomenko ženska ali pridevnikom ženski. V SSKJ2 je učiteljica »1. ženska, ki (poklicno) uči, poučuje«, antijunakinje v slovarju ni, junakinja je »1. ženska, ki je storila izredno pogumno, junaško dejanje «, boginja pa »1. v mnogoboštvu žensko božansko bitje «. ${ }^{1}$

Pri slovarskih razlagah poimenovanj za osebe, ki temeljijo na analizi po slovarskih kriterijih zbranega gradiva, ${ }^{2}$ torej ločujemo spolno nezaznamovane in spolno določene razlage. Analiza SSKJ2 je pokazala, da je "spolno nezaznamovana raba najpogosteje povezana z moškim slovničnim spolom « (Štumberger 2019: 206), v slovarju pa najdemo tudi spolno nezaznamovane izraze za poimenovanja oseb v srednjem in ženskem slovničnem spolu. Spolno nezaznamovani prvi pomen v ženskem slovničnem spolu imajo nevtralna poimenovanja priča, žrtev, oseba; čustveno zaznamovana poimenovanja so brblja, brbra, cmendra, cmera, cmerda, cmerga, čveka, negoda, nerga, prismoda, zguba, žlabudra, žlobudra, žužlja, žužnja, blebetulja, klepetulja, cmerika, jokica, propalica, jera/Jera, mila jera/Jera. Spolno nezaznamovani pomen v srednjem slovničnem spolu ima nevtralno poimenovanje bitje, čustveno zaznamovana poimenovanja so cepetalo, človeče, dremalo, gobezdalo, hacalo, vreščalo, zaspane, zijalo, zmene, žužnjalo, bitjece. ${ }^{3}$

\section{Poimenovanje ženskih oseb v slovenskih besedilih}

Pri poimenovanju ženskih oseb je izbira slovnične oblike odvisna od tega, ali so skupine po spolu sestavljene samo iz žensk ali spolno mešane: „Oblike za ženski spol so mogoče le, če so sporočevalka in vse udeleženke ženskega spola. Če bi se sporočevalka v spolno mešani skupini izrekala v oblikah za ženski spol, bi bilo njeno izražanje zaznamovano; nagovarjala bi samo ženske« (Kunst Gnamuš 1994/95: 258).

V besedilih lahko torej "slovnični moški spol prevzame vlogo nadpomenke« (prav tam: 259), to pa velja tudi za primere, ko ženske v določenih poklicih prevladujejo. Tako ni nobenega dvoma, da bodo stavkali tako učitelji kot učiteljice ali vzgojiteljice in vzgojitelji, čeprav je v naslovu časopisnega članka samo moška slovnična oblika, npr. Učitelji in vzgojitelji bodo stavkali za valentinovo

1 Zgledi so iz Štumberger 2019.

2 Uvod v SSKJ2, § 12: „Slovarsko gradivo prve izdaje Slovarja slovenskega knjižnega jezika je bilo izpisano iz 3357 enot oziroma 5128 knjig, in sicer iz leposlovnih del, revij, časopisov, poljudnoznanstvenih del in šolskih knjig. Zelo redke so besede, za katere ni bilo izpisov. Gradivo zanje je bilo prevzeto iz Pleteršnikovega slovarja ali iz Slovenskega pravopisa 1962, včasih pa tudi z listkov s podatki, ki so jih po svojem vedenju zapisali uredniki. Iz vsega gradiva je bila za prikaz v slovarju odbrana približno tretjina iztočnic. Gradivni viri za dopolnitve, ki jih prinaša druga, dopolnjena in deloma prenovljena izdaja, so bili zlasti besedilni korpusi Nova beseda, Gigafida in Kres. Izbor besedja, prikazanega v slovarju, je nastal glede na pogostnost pojavitev v gradivu. «

3 Zgledi so iz Štumberger 2019: 207. 
(STA, Marko Rabuza 2017). Moška slovnična oblika ima v besedilih dva pomena - uporabljamo jo za označevanje samo moških ali spolno mešanih skupin.

V zvezi z rabo moških slovničnih oblik opozarjam na to, da so po drugi svetovni vojni poskušali uvesti rabo moških slovničnih oblik tudi za označevanje konkretnih ženskih oseb (Pogorelec 1997: 5, opomba 8):

Dosledno rabo nadspolne moške oblike v nomenklaturi poklicev in funkcij so v prvih dveh povojnih desetletjih uveljavljale tudi ženske funkcionarke in ženske organizacije. Drugačna raba $v$ medijih je bila $v$ določenem smislu znak neodobravanja ne le jezikovne oblike, ki je bila v dveh stopnjah prenesena iz tujih jezikovnih vzorcev in tujih ideoloških podstav, sovjetske ruske in od tam srbohrvaške, od koder so jo prevzeli v uradno slovenščino, ampak tudi tuje ideologije. Nemara je tudi v tem tujstvu jezikovnega in ideološkega znaka razlog za drugačno medijsko rabo in postopno drugačno uveljavljanje ženskih poimenovanj, kar pa je seveda nasledek postopnega dozorevanja domačih gibanj za žensko uveljavitev.

Raba nadspolne moške oblike za poimenovanje ženskih oseb je torej povezana z vplivom ruskega in srbohrvaškega jezika, to pa potrjuje tudi raziskava časopisov Slovenski poročevalec in njegovega naslednika Delo za izbrane številke iz leta 1945, 1969 in 2000. Največ rabe nadspolne moške oblike za znane ženske osebe je bilo v časopisu Slovenski poročevalec leta 1945, leta 1969 je bila v Delu taka raba zabeležena samo v enem besedilu, leta 2000 pa ni bilo v pregledanem časopisu niti enega primera (Umek 2008: 84).

Zgledi iz leta 1945:

Sestava Narodne vlade Slovenije

Imenovani so:

[...] za ministra za socialno politiko: Vida Tomšič (Slovenski poročevalec VI/16, 8. 5. 1945, str. 1).

Lidija Šentjurc v imenu Centralnega komiteja KPS: Tovariši in tovarišice! Navdaja me posebna radost, da kot star ilegalni delavec $v$ Ljubljani lahko danes pozdravim v imenu CK KPS ta veličastni zbor delegatov mesta Ljubljane (Slovenski poročevalec VI/24, 20. 5. 1945, str. 2).

Minister za socialno politiko tov. Vida Tomšič je dala dopisniku TANJUG-a na njegova vprašanja naslednja pojasnila (Slovenski poročevalec VI/52, 20. 6. 1945, str. 2).

Analiza zgledov rabe moške slovnične oblike za konkretne ženske osebe kaže, da se v besedni zvezi samostalnik ujema s pridevnikom, glagol pa je v ženski slovnični obliki, npr. star ilegalni delavec, minister za socialno politiko tov. Vida Tomšič je dala [...].

Drugačno rabo kot poimenovanje funkcij kažejo oglasi za delo, v katerih najdemo tudi obojespolna poimenovanja: 4

4 Vsi zgledi so iz Slovenskega poročevalca VI/39, 6. 6. 1945, str. 39. 
TAJNIKA ali tajnico išče Društvo slepih v Ljubljani za dve uri popoldne. Ponudbe poslati na Društvo slepih. Ljubljana, Gradišče 7.

PROFESORJA(ico), dobrega, za angleški jezik iščem. Ponudbe na upravo pod »Angleščina«.

Vajenci(-ke)

DEKLE išče mesto šiviljske vajenke. Ponudba pod »Vajenka«.

Hišnika ali hišnico SPREJME VEČJE PODJETJE. - Zaželen je delaven, zanesljiv in pošten zakonski par. - Nastop 1. julija t. I. Naslov v upravi "Slovenskega poročevalca«.

\section{Raba ženskih poimenovanj v starejših besedilih}

Jezikovni vzorci "so se oblikovali v jeziku v stoletjih razvoja, razlikovanje po spolu je razvidno tako v govorjenem kot v pisanem jeziku (Pogorelec 1997: 6). Analiza slovenskih besedil je pokazala, da sta v Brižinskih spomenikih »le dve ženski poimenovanji: Prvo, lastno, se v sodobni pisavi glasi sveta mati Marija, sicer so v nebeškem moškem svetu navzoče le še deve pravdne = pravične device $\mathrm{v}$ prvem in device $\mathrm{v}$ tretjem spomeniku. Duhovnik nagovarja $\mathrm{v}$ svojem besedilu le sinove in se šteje k bratom [...] (prav tam: 6).

V Stiškem rokopisu (1428-1444), kot navaja B. Pogorelec, so razlikovali "med svetiki in sveticami, starejšo obliko današnje dvojnice svetniki, svetnice« (prav tam: 6, op. 11). V Černjejskem rokopisu s konca 15 . stoletja najdemo »izraz gospodinji (= starejša oblika za gospodinja) ob moškem gospodar (prav tam: 6), poimenovanje Doctorza pa je kot prevod nemške besede Doctorin zapisano v Trubarjevi Hišni postili (Merše 2013: 191, op. 344): "Žensko poimenovanje se nanaša na Jezusovo mater Marijo: ona ta velika Doctorza inu Prerokynja, katera ie vuzheneifha, kakor vfi Apostoli inu Preroki, te lube Elizabethe peiftinja inu Kluzhariza poftane (TPo 1595: III, 133)."

Rabo ženskih poimenovanj B. Pogorelec povezuje s spolnim zaznamovanjem konkretne osebe, to pa je obstajalo tudi pri priimkih, kakor kaže primer oporoke Barbare pl. Kazianar iz 17. stoletja, ki se je podpisovala kot "Barbara Kazianerica vdova frai(n) oziroma Kazianarica (Pogorelec 1997: 7). Za 17. stoletje za tvorbo ženskih poimenovanj iz moških priimkov B. Pogorelec navaja naslednja obrazila (prav tam: 8): -ca/-ica, -ka, -ovka, -la, -ula z zgledi Zagorec - Zagorčevka, Gornik - Gornikovka, Bister - Bistrovka, Smole - Smoletovka, Osole - Osoletovka ali Osolela, Volk - Volkula. Pri tvorjenkah gre za »izpeljanke iz svojilnega (pripadnostnega) pridevnika, kar pa nakazuje še dodatno semantično prvino ženskih poimenovanj, pripadnost $\mathrm{k}$ nekomu, $\mathrm{k}$ družini, rodu, možu« (prav tam: 8).

Pri ženskih poimenovanjih imamo za priimke v slovenščini »poleg moške oblike priimka, ki je veljala po matičnih knjigah od 17. stoletja za osebe obeh spolov « (prav tam), za ženske v splošni pogovorni rabi iz priimka tvorjene svojilne pridevnike (prav tam: 8):

Ta oblika se je $v$ socialnem spreminjanju slovenskega jezika in ustaljevanju norme uveljavila tako $v$ urbanem kot $v$ ruralnem okolju in polagoma izpodrinila nekdanje samostalniške tvorbe, ki presoje knjižne primernosti niso prenesle. Toda oblika s svojilnim pridevnikom namesto priimka nosi zaradi distribucije 
Janez Tovornik na eni in Ana Tovornikova na drugi strani primes jezikovne neenakopravnosti in tudi neuradnosti. Taka raba je zelo pogosta $v$ govoru, posebej opazna je $v$ medijih.

\section{Poimenovanja s pomenom (zakonska) žena}

S pomenskega stališča so zanimivi primeri, »ko poimenovanje ženske, besedotvorno motivirano s poimenovanjem položaja, poklica ali kako drugače izpostavljene družbene dejavnosti moškega, pomeni v prvi vrsti ali samo (zakonsko) ženo« (Vidovič Muha 1997: 70). V Slovarju slovenskega knjižnega jezika (SSKJ) je 75 leksemov s pomenom 'zakonska žena', označeni pa so na naslednje načine (Štumberger 2019: 207):

1. s časovno-frekvenčnim kvalifikatorjem starinsko: ${ }^{5}$ starešinka, stotnica, svetnica, županja, načelnica, organistovka, pekovka, polkovnica, popadija, popinja, popovka, ribičevka, črednica, dacarka, davkarica, dimnikarica, doktorica, glavarka, glavarica, gozdarica, gubernatorica, guvernerka, hišnica, hotelirka, kajžarica, kapitanka;

2. s časovno-frekvenčnim kvalifikatorjem zastarelo: ${ }^{6}$ sodnica, sodnikovka, generalica, generalka, kapetanica;

3. s časovno-frekvenčnim kvalifikatorjem redko: ${ }^{7}$ prestolonaslednica, cerkovnica, doževka;

4. s kvalifikatorskim pojasnilom: vojvodinja v nekaterih deželah, šahinja zlasti v iranskem okolju, nekdaj, vikontésa v Franciji, bankirka v nekaterih deželah, bazilisa v bizantinski državi, begovica v fevdalni Turčiji; 5. brez časovnega kvalifikatorja: viničarka, žagarica, graščakinja, grofica, grofinja, banica, bajtarica, baronica.

Analiza Slovarja novejšega besedja slovenskega jezika (SNB) je pokazala, da je pri teh poimenovanjih lahko prišlo do spremembe pomena 'zakonska žena' v 'žensko, ki opravlja določen poklic ali je nosilka čina', npr. notarka, bankirka in majorka (Štumberger 2015: 102-103). V SSKJ2 so ti pomeni navedeni kot prvi:

\section{SSKJ}

notárka -e ž (ā) star. notarjeva žena: jezikava notarka; dacarka in notarka

SNB

notárkaSSKJ8 - e ž, člov. (ā)

ženska, ki poklicno sestavlja pravne listine z uradno veljavnostjo, izdaja potrdila, overovlja podpise,

5 "Beseda, pomen ali zveza, ki je bila nekoč (v kaki funkciji) splošno rabljena; danes ima arhaično patino (ajd, akoravno)« (SSKJ, § 154).

6 »Nekoč rabljena beseda, pomen ali zveza; danes je v knjižnem jeziku mrtva (blagajnica, diviti se). O tem, kakšno stilno vrednost je imela tako kvalificirana beseda nekoč, slovar ne daje pojasnil« (SSKJ, § 155).

7 "Beseda, pomen ali zveza, ki je sicer v splošni rabi, pa je v razmerju do sinonima precej redka (bogataška, dopoldneven)« (SSKJ, § 153).

8 SNB, Uvod (9): „Zaradi večje praktičnosti je neposredno navezovanje na iztočnice v SSKJ pokazano s posebnim grafičnim znamenjem SSKJ, ki obvešča, da gre za nov pomen že uslovarjene besede (čarovnikSSKJ rač., okuženSSKJ rač.) ali širjenje njenega pomena v novih besednih zvezah (optičnisskJ optično vlakno)." 


\section{Ustvarjalke v slovenskem jeziku, literaturi in kulturi}

prepise: overiti podpis pri notarki; urad notarke; Notarka je bila imenovana na podlagi predloga notarske zbornice, ki je od enajstih kandidatov, kolikor se jih je prijavilo na razpis, ministru predlagala $v$ imenovanje tri kandidate $\mathbf{E}(\uparrow)$ notár

SSKJ2

notárka -e ž (ā)

1. ženska, ki poklicno sestavlja pravne listine z uradno veljavnostjo, izdaja potrdila, overovlja podpise, prepise: notarka je bila imenovana na podlagi predloga notarske zbornice; overiti podpis pri notarki; pisarna notarke; odvetnica in notarka

2. star. notarjeva žena: jezikava notarka; dacarka in notarka

Geslo notarka ima v SSKJ kvalifikator starinsko ${ }^{9}$ in pomen 'notarjeva žena'. Notariat je na slovenskih tleh obstajal »od 21. 5. 1855, ko je bil sprejet avstrijski notarski red, ki je veljal tudi v slovenskih deželah tedanje Avstrije. Latinski tip notariata je bil dne 17. 11. 1944 z odlokom Avnoja na celotnem območju Jugoslavije odpravljen« (Omerzu 2013: 11), zato se razlaga in kvalifikator v SSKJ nanašata na čas pred drugo svetovno vojno. Notariate so kasneje ponovno uvedli 1. 6. 1995 (Cirkulan 2009: 18), iz tega časa pa je razlaga v SNB '̌̌enska, ki poklicno sestavlja pravne listine z uradno veljavnostjo, izdaja potrdila, overovlja podpise, prepise'. V SSKJ2 so nato oba pomena zapisali v enem geslu, na prvem mestu pa je novejši pomen.

\section{Poimenovanja ženskih oseb po njihovi dejavnosti, poklicu, funkciji}

Kot sem pisala v poglavju o poimenovanju ženskih oseb v slovenskih besedilih, so v slovenski javni rabi po drugi svetovni vojni "sprva $v$ uradnih besedilih, $v$ listinah in dokumentih, pa tudi v svečanem oficialnem izražanju« (Pogorelec 1997: 5) poskušali uvajati poimenovanja v moškem slovničnem spolu tudi za ženske osebe, »v drugih besedilih, predvsem pri medijskem poročanju, pa se ta vzorec, ki je nastal pod vplivom neustrezne ideološke podlage, ni obnesel. Pri poročanju o konkretnih ženskih osebah so že v petdesetih in šestdesetih letih zlasti na radiu, kasneje tudi na televiziji dosledno uveljavili žensko obliko naziva, torej profesorica, direktorica« (prav tam: 5).

Navedbo o rabi naziva profesorica "že v petdesetih in šestdesetih letih « dopolnjujem z raziskavo časopisa Slovenski narod, katerega prva številka je izšla 2. 4. 1868, zadnja, ki je dostopna v digitalni knjižnici dLib, pa ima datum 30. 4. 1945. V Slovenskem narodu najdemo izraz profesorica že leta 1920, torej raba v petdesetih letih ni bila novost in posledica jezikovnega razvoja po drugi svetovni vojni (Slovenski narod LIII/154, 9. 7. 1920, str. 2):

Društvo hrvatskih srednješolskih profesorjev je imelo v nedeljo dne 4. julija svojo glavno skupščino, ki ji je predsedoval predsednik dr. P. Karlič. Ljubljansko profesorsko društvo je zastopal njega predsednik dr. Koran, beogradsko pa profesorica Milena Petrović in prof. Miodrag Ristić. Najvažnejša točka dnevnega reda je bila razprava o pravilih centralnega profesorskega društva za vso Jugoslavijo. Profesor Ristić je v svojem pozdravnem govoru naglašal, da je pripravljalni odbor ona pravila sprejel enoglasno, dasi so v njem sicer člani jako različnih naziranj in da pravila puščajo pokrajinskim organizacijam popolno samo-

9 Gl. op. 5. 
stalnost dela in imetka. Profesorica Petrović je v umno zasnovanem govoru povdarjala, da mora naša šola vzgajati enoten tip. t. j., naj bi se vsak Srb čutil enako Hrvata in Slovenca in obratno.

Z besedilnega stališča je zanimivo opazovati, kako je profesorica drugače od svojih kolegov najprej poimenovana tudi z imenom, nato pa z nazivom profesorica in priimkom. Razlogi za to so povezani s slovenskim jezikom, kajti z okrajšavo naziva in imena ne bi mogli izraziti ženskega spola.

Kaže, da je bila raba ženskih poimenovanj za poimenovanje konkretnih žensk razširjena daleč pred drugo svetovno vojno, tudi v časopisu Slovenski narod pa so za prvo doktorico Univerze v Ljubljani Ano (oz. Anko) Mayer zapisali žensko obliko (Slovenski narod LIII/158, 15. 7. 1920, str. 3):

Prve promocije na ljubljanski univerzi se bodo vršile jutri, dne 15. julija, ob 11. uri v bivši deželnozborski dvorani (deželni dvorec). Promovirani bodo trije kandidati, in sicer: filozofinja Anka Mayerjeva iz znane narodne rodbine iz Vipave in pravnika Mirko Kuhelj in Pavel Suver iz Ljubljane.

\section{Zaključek}

Čeprav je informacija o tem, da je bila prva oseba z doktorskim nazivom na Univerzi v Ljubljani ženska in da je raba ženskih poimenovanj potrjena tudi v najstarejših slovenskih besedilih, splošno znana, se v javnosti brez analize slovenskih besedil pojavljajo naslednje trditve (Jogan 2019: 39, zapis okrogle mize Jezik in spol, 23. 10. 2018):

Ko je doktorica Štumberger rekla, da so se po drugi svetovni vojni začeli ... se je začel uporabljati moški generični spol za ženske, ki so delale. Ja, seveda, saj so šele po drugi svetovni vojni imele pravico, da so se prej že došolale in da so lahko vstopale, ker so bile ustavno izenačene, recimo v tem prostoru, lahko vstopale v vloge, ki so prej imele samo moško oznako.

Ženske so lahko na Filozofski fakulteti na Dunaju študirale od leta $1897,{ }^{10}$ zato ugotavljam, da trditev o tem, da naj bi bil mejnik druga svetovna vojna, ne drži. Da so lahko ženske na ljubljanski univerzi študirale vse od njenega začetka, poleg informacije o prvi osebi z doktorskim nazivom, ki je bila v Sloveniji ženska, kaže tudi rektorjev zapis ob 100-letnici Univerze v Ljubljani (Papič 2019: 13):

V prvem študijskem letu 1919/1920 je bilo na univerzo vpisanih 942 študentov, od tega 28 žensk in 914 moških. Kljub temu da so močno prevladovali moški, pa je bil prvi doktorski naziv podeljen ženski, kar je bila redkost tudi v evropskem merilu. Leta 1920 ga je prejela Ana Mayer za disertacijo z naslovom O učinkovanju formalina na škrob.

Poleg informacije o številu žensk prvo študijsko leto na Univerzi v Ljubljani je za jezikoslovno obravnavo pomenljiva raba spolno vključujočega moškega slovničnega spola - samostalnik študent v množini očitno vključuje tako ženske kot moške. Jezik je torej toliko vključevalen, kolikor je vključevalna družba.

10 Zanimivo je, da je to informacijo pred prej citiranim delom na okrogli mizi podala tudi Maca Jogan (2019: 38). 


\section{Ustvarjalke v slovenskem jeziku, literaturi in kulturi}

\section{Viri}

Slovenski narod LIII/154 (9. 7. 1920); LIII/158 (15. 7. 1920).

Slovenski poročevalec Vl/16 (8. 5. 1945); Vl/24 (20. 5. 1945); Vl/39 (6. 6. 1945).

\section{Literatura}

BAJEC, Anton idr. (ur.), 1994: Slovar slovenskega knjižnega jezika. Ljubljana: Založba ZRC, ZRC SAZU. www.fran.si (dostop 29. 5. 2020)

BIZJAK KONČAR, Aleksandra, SNOJ, Marko (ur.), 2014: Slovar novejšega besedja slovenskega jezika. Ljubljana: Založba ZRC, ZRC SAZU. www.fran.si (dostop 29. 5. 2020)

CIRKULAN, Monika, 2009: Notar in njegove pristojnosti na področju uprave. Ljubljana: Fakulteta za upravo.

JOGAN, Maca, 2019: Okrogla miza »Jezik in spol«. Slovenščina 2.0 VII/2. 38-40.

KUNST GNAMUŠ, Olga, 1994/95: Razmerje med spolom kot potezo reference in spolom kot slovnično kategorijo. Jezik in slovstvo XL/7. 255-262.

MERŠE, Majda, 2013: Slovenski knjižni jezik 16. stoletja: razprave o jezikovnem sistemu, besedju in prevodni problematiki. Ljubljana: Založba ZRC, ZRC SAZU.

Okrogla miza »Jezik in spol«, 2018. Ljubljana: Filozofska fakulteta, 23. 10. 2018. www.youtube.com/watch?v=3DhQQzpOHzA (dostop 1. 6. 2020)

OMERZU, Nataša, 2013: Dostopnost računovodskih podatkov o poslovanju notarske dejavnosti v Sloveniji. Delo diplomskega seminarja. Maribor: Ekonomsko-poslovna fakulteta.

PAPIČ, Igor, 2019: Ob stoletnici Univerze v Ljubljani. Uvodnik. Ljubljana XXIV/9, november 2019. 3.

POGORELEC, Breda, 1997: Slovenska skladnja in poimenovanja ženskih oseb. Aleksandra Derganc: Dodatek k 33. Seminarju slovenskega jezika, literature in kulture. Ljubljana: Filozofska fakulteta, Oddelek za slovanske jezike in književnosti.

Slovar slovenskega knjižnega jezika, 2., dopolnjena in deloma prenovljena izdaja [= SSKJ2]. https://fran.si/iskanje?Filte redDictionarylds $=133 \&$ View $=1$ \&Query $=\% 2 A$ (dostop 3. 6. 2020)

STA, Marko RABUZA, 2017: Učitelji in vzgojitelji bodo stavkali za valentinovo. SiolNet, 15. 12. 2017. https://siol.net/ novice/slovenija/ucitelji-in-vzgojitelji-bodo-stavkali-za-valentinovo-455599 (dostop 3. 6. 2020)

ŠTUMBERGER, Saška, 2015: Veränderungen in der gesellschaftlichen Stellung von Frauen in Slowenien seit 1991: Personenbezeichnungen im Wörterbuch Slovar novejšega besedja slovenskega jezika (2012). D. Scheller-Boltz (ur.): New Approaches to Gender and Queer Research in Slavonic Studies. Wiesbaden: Harrasowitz (Die Welt der Slaven 59). $101-109$.

ŠTUMBERGER, Saška, 2019: Slovarska obravnava samostalnikov za poimenovanje oseb. Slavistična revija LXVII/2. 203-211. https://srl.si/ojs/srl/article/view/2019-2-1-8 (dostop 29. 5. 2020)

UMEK, Neža, 2008: Feminizacija v slovenščini in francoščini: družbeni in/ali jezikovni problem? Diplomsko delo. Ljubljana: Filozofska fakulteta, Fakulteta za družbene vede.

VIDOVIČ MUHA, Ada, 1997: Prvine družbene prepoznavnosti ženske prek poimenovalne tipologije njenih dejavnosti, lastnosti. Aleksandra Derganc (ur.): Ženska v slovenskem jezik, literaturi in kulturi. 33. SSJLK. Ljubljana: Filozofska fakulteta. 69-79. 